\title{
EMPLOYMENT, MENTAL HEALTH AND ECONOMIC RATIONALITY AT AN AGE OF NEO- LIBERAL GLOBALISATION
}

\author{
Assoc. Prof. Lila Antonopoulou, Aristotle University of Thessaloniki, Department of \\ Economics, lanton@econ.auth.gr \\ Christina Dervisi, Research Collaborator, Aristotle University of Thessaloniki, \\ Department of Economics.
}

\begin{abstract}
The present study examines the place of the mental health sufferers within the current labour market, with particular emphasis on the economic and social prospects sufferers from mental disorders may have, as well as on the concrete possibilities for their integration in the labour market. The study's central question is the following: are there any real prospects for integration of mental sufferers in a labour market dominated by conditions and practices of ruthless capitalism, or are we in a reality witnessing a renewed attempt at excluding mental sufferers from the social dynamic, given that the dominant economic reason requires the dependence of employability of a person on his/her cognitive skills and on his/her capacity to submit this mentality to the requirements of the prevailing market conditions?

The study attempts to address these issues by questioning the recent Mental Reform Act promulgated in Greece. Our analysis of the Act is supplemented with a theoretical exploration of the relationship that exists between economic rationality and the psychological normality with a view of diagnosing the contribution of the former in the determination of the latter within the context of contemporary labour relations.
\end{abstract}

Key Words: Labour market, Mentally disable, Normalcy

\section{INTRODUCTION}

According to the approaches of alternative psychiatry, rehabilitation of mental health sufferers entails their reintegration in the society, the working environment, the interpersonal relations, the rights, the dialectic of controversies and differences/conflicts (Basaglia 2000). 
Such imperative is anything but self-evident to the prevailing economic viewpoint given that "the hope of living in a better place" is nowadays dissociated from the field of collective reasoning, research and politics.

It is true that the deregulation of labour relations has severely aggravated the problems caused by the preponderance of economism and utilitarianism. Such problems threaten social cohesion and the role of politics. Since the beginning of the 80 's, the dogma of neo-liberalism has established its dominance, while employers have increasingly come to question the status of the Fordist model governing industrial relations. At the same time, the introduction of new technologies transforms the labour markets. Heterogeneous forms of employment tend to supersede having as dominant characteristic the polarisation between highly-paid and lower-paid working men (Boyer 1995). A portion of the labour force continues to maintain the benefits of Fordism, while simultaneous sections in the chain of the production process are relocated to countries with lower labour cost.

The employees in the countries of advanced capitalism are more and more possessed by a sentiment of insecurity in relation to the prospects of keeping their job, while the intensification of manual, and also of intellectual work, constitutes a fertile ground for the creation of mental disorders, such as stress and depression, especially at a time when mental health is extremely important and vital for all citizens, for society and for growth. According to a study of the European Commission (Green Bible for mental health), bad mental health is affecting one out of four employees and it can lead many times to suicide. It also undermines the economic apparatus, as well as the educational institutions, the correctional system and the legislation (Commission Européenne 2005).

Within such context, the conventional economist shows no interest for those who lose out in a free market economy, since they do not fulfil the criteria of the type of employee required by capitalism. This new type of employee does not only sell its natural labour power, but also its creativity, imagination and availability (Lipietz 1998). One therefore may wonder what kind of interest the conventional economist may have in people who do not comply with the detailed specifications and standards laid out by the new labour market. Thus, economic science is invited to explore the subject by setting aside its characteristics as a corpus of profit-making and lucrative techniques and by emphasizing, instead, its humanistic dimension.

In view of the above, the goal of the present study is to examine the economic and social prospects of integration or reintegration of mental health sufferers in the labour market. The central question is coined as follows: within a globalised environment dominated by ruthless capitalism is there a place for mental health sufferers, or are we witnessing an attempt that aims at excluding them completely from all kind of employment, especially when one takes into account the fact that the dominant economic reason contends that the employability of a 
person depends on his/her cognitive skills and on his/her capacity to submit this mentality to the requirements of the prevailing market conditions? The fist part of this analysis refers to the recent mental health reform that took place in Greece and to the impediments encountered during its implementation. The second part explores at a theoretical level the relationship between economic rationality of classic and neo-classic economists, on one hand, and psychological normality, on the other hand. The examination aims to identify and analyse the contribution of economic rationality to the formulation of psychological normality in today's industrial relations.

\section{THE MENTAL HEALTH REFORM IN GREECE AND THE DIFFICULT SOCIAL REINTEGRATION OF MENTAL HEALTH SUFFERERS}

Mental health reforms in Greece started in the mid 80s, as part of the creation of a system for National Health Service. The aim of the mental health reform was the transformation of the entire approach of psychiatry by means of shifting from the logic and practice of the asylum towards a logic and practice that is more human-centred (humanistic).

The modernisation of mental health services around the country was precipitated (big asylums were shut down and were replaced by smaller more flexible units) especially under the pressure of the international outcry concerning the medieval conditions of mental health care provided by the Leros asylum in the Dodecanese.

Community reintegration of mental sufferers became the major objective of the reforms. To this end, the contributions of the international and European community were pivotal. In the beginning of 1990 the European Union set up a special fund for the implementation of mental health reforms in Greece, and in 1999 as a result of the EU financial assistance the Greek government formulated a ten year programme, named 'PsychArgos' (Official Gazzete of the Hellenic Republic 1999), which emphasised, among other things, the social integration, reintegration and entry into the labour market of mental sufferers (Psychargos 2009).

To the present day, after a series of reviews to the programme and a ten year extension period granted in 2004, one can ascertain that (albeit the deficiencies) there is a certain infrastructure for the support of the social reintegration of the mental sufferers, nevertheless it is hard to contend that the 'PsychArgos' programme has effectively overcome the imperative obstacles that predominate in the field of the subject of our study. Moreover, due to the short fallings experienced during the implementation of the programme, many psychiatrists and practitioners working in it believe that the latter's progress is stalled and that the programme merely serves as an alibi, let alone the fact that it has not achieved its aims and objectives (Union of Psychiatric Hospital of Athens 2003). 
Any progress achieved regarding the infrastructure necessary for the social reintegration of mental sufferers has so far been in the establishment of educational workshops, in the form of limited liability cooperatives, for the professional integration of mental sufferers. There are twelve such cooperatives operating today in Peloponnese, Athens, Thessaloniki, Leros, Chios and Corfu, whereas by the year of 2010 there's a plan to open in total 55 such places throughout Greece (Programme, Equal 2005). However, to the present day, the operation of such workshops has not shown encouraging signs of guaranteeing an acceptable standard of living for mental sufferers. Salaries and wages in these workshops are scandalously low (at 150 euros per month - Warner 2004) and they cannot possibly promote and sustain the independence and autonomy of mental sufferers in the labour market.

On the other hand, the removal of the exclusion of mental health sufferers from the labour market has been met with insurmountable obstacles. A recent report conducted by the same programme reveals that "A considerably large number of employers regard mental sufferers either as incapable to work, or as potentially dangerous. Even when the latter are employed, it is frequently the case that they lose their job on the slightest deterioration of their condition, when the financial support provided by the state comes to an end (Psychargos 2009). What aggravates the social exclusion of such persons is the stigma of being a 'mental health sufferer', which is acutely felt especially in Greek rural provinces, but also to a certain extent, in big urban cities, where opposition and protest against the opening of psychiatric guests' houses is very frequent. In addition, a climate of fear over the perceived 'danger' that mental sufferers can procure, also whipped up by the media, further contributes to their exclusion and isolation. It must be said that Greece is not the only country experiencing the social denigration of mental health sufferers, since the Green Bible of the European Commission of 2005 (Commission Européenne 2005) lists a plethora of major problems throughout the European Union, and identifies racism and prejudice as the sources of the stigma attached to mental sufferers.

Exacerbating the plight of social exclusion and isolation and the enormous difficulties mental sufferers are facing in entering the labour market is the total deprivation of their housing needs. Indeed, while the majority of big asylums (that used to operate in Petra of Mount Olympus, in Chania of the island of Crete, in Tripoli of Peloponnese and in Corfu) have been shut down, they have not yet been replaced with modern, multiple structures, smaller units. A direct consequence of this situation is the alarming increase of homeless mental sufferers. In particular, it has been noted that around a sixth of the homeless population in Greece suffer from mental problems (Megalooikonomou 2006).

The social exclusion experienced by mental health sufferers coincides with the intense competition that dominates nowadays the economic relations and pushes individuals of fragile mental health to pay the biggest price by being the victims of such situation. Thus, irrespective of mental health reforms and the drive for social and professional integration of mental sufferers, the fact is that at present the re-admission rate to mental health institutions in Greece amounts to 
$40 \%$ of total admissions to such institutions (Gkionakis 2009). This is an evident proof of the deterioration of the conditions of mental health sufferers, especially in the light of a general pathological situation reflected in the current state of economic affairs.

From the Greek data above, one can draw the conclusion that there is a conflict between the rhetoric of mental health reforms and the actual reality. Such divergence can be properly understood within the context of modern capitalistic restructuring. On a global scale, we are now all facing not the much touted notion of a two-thirds society, but with one where the majority of the middle class is forced down to the base of the pyramid (Lipietz 1998. Photopoulos 2008). Within the global framework of the formulation of the social structure, the situation in Greece appears particularly alarming, especially regarding graduate unemployment, de-industrialisation and the slow pace of modernisation of services. In such a climate the economic and social exclusion of vulnerable persons is inevitable. The situation in the employment market, the measures and ideologies of Neo-liberalism establish the supremacy and pre-eminence of employability. The notion of employability is used to inculpate the long-term unemployed, the young and the vulnerable people. Under the prevailing ideology, the above groups are made to feel culpable for their predicament, as the burden of responsibility shifts from the public sphere and the society to the individual and the private. "A community free of its own guilt put its citizens into a fragile and brittle situation. This sense of guilt leads them to accept any kind of employment, without taking into account their expectations, educational background and prior work expertise" (Lebaube 1990). Thus, one can wonder what are the consequences of economic imperialism on the formulation of psychological normality based on the imperatives of economic rationality. This question constitutes the subject of study of our next section.

\section{PSYCHOLOGICAL NORMALITY AND ECONOMIC RATIONALITY}

Every society considerably defines the criteria of its rationality. Capitalism, likewise, produces and imposes its own model of rationality both in theory and in practice. Its most clear expression is to be found in the reason of the economic science, where the rational combination of factors of production towards the achievement of an end, appears as the very embodiment of reason itself, consigning all historical past to the chaos of an irrational barbarism. According to Oscar Lange "the principle of economic rationality is the principle of every human rational activity, which tends to implement to its maximum any given end" (Lange 1962, Godelier 1974).

Scientism at our age requires for psychological normality to be a major factor for determining human behaviour. Medicine in general and psychiatry in particular introduce into the psychical universe the pair of 'normal-pathological' as a criterion for discerning human behaviour. Since the 17th century - during which 
Michel Foucault (1979) puts the beginning of the "big incarceration"- mental sufferers have found themselves in hospitals together with beggars and the poor. This marks the beginning of the asylum, which will become par excellence the fundamental psychiatric institution in the 19th century.

The asylum first opened its gates at a time of burgeoning capital and scientific progress and emerged as the result of such achievements. From the 19th century until today, there has been a tendency in attributing to the notion of psychological normality a biological status, which expresses the trend for a series of phenomena and symptoms of an undisputed social and political aspect to be considered as innate characteristics.

Such a tendency became apparent after World War II. The various psychological techniques were devised for the assessment of the social behaviour of persons (especially in the work place) with a view to influence and predict human reactions together with efforts to "socialise" 'unsociable' persons. All the above leads us to examine the possibility of a partial overlap between economic rationality and the well respected notion of mental normality. One could not fail to notice that the rationality of the 'homo economicus' of the classics and neo-classics is enriched with psycho-sociological elements without undermining the core of the official economic theory, whereas the notion of psychological normality is increasingly adjusting to the rules of triumphant economism. The mental sufferer is required to adjust and function in a highly commercialised society and its economy. F. Basaglia (2000) characteristically describes this kind of adaptation in the following example:

"The reintegration of a patient passes through the reintegration of its powers of labour, on the condition that there is work available. If there is no work, there is no reason for reintegration. In England, for example, many patients were released from psychiatric clinics, but a large number of them returned as the economic downturn forced them back".

The mitigation techniques with which labour relations are dealt during the metaFordism era, point out the extent to which a person's ability for adjustment constitute a precondition for its ability to keep a job. Economic reasoning, thus, becomes a criterion of the rationality of a sociable human being.

But if by 'rational' one understands the ability to act in accordance with reason, then such reason is subject to historical (selffformation and, in turn, subject to an examination of its historical formation (Castoriadis 1991). Reason, in the classical sense of the term consists of cognitive, moral and aesthetic dimensions (Weisskopf 1978). In the contemporary society it is progressively confined to its cognitive nature.

It is therefore necessary that the power relates the principle of economic rationality to a notion that carries an undisputed scientific status. If we consider psychological normality as a precondition for rational behaviour we 
automatically accept the preponderance of economic rationality as socially required and legitimate and further endow economic reason with the revered status of a normative principle.

The fundamental imperative of our system requires today that a wholly rational working man must also possess the 'qualities' of being employable and must be considered to be wholly responsible for it. Modern economies, both at the secondary and tertiary sector, are in need of a 'technology' of behaviour to be used both in the workplace and outside in the society at large. Psychology and psychiatry have made many contributions to the conformity and adaptability of persons. From B.F. Skinner's behaviourism to contemporary psycho-techniques governing labour relations, one can find the same determination on turning a person into an element that is functional and useful to the economic machinery.

\section{CONCLUSIONS}

Partial identification of economic rationality with psychological normality is, in our view, a consequence of a generalized commercialisation. The essence of dominant economic reason -i.e., maximisation at all costs- casts a spell over all forms of social knowledge and behaviour.

Economic rationality acquires the status of a normative and leading principle, while at the same time it constitutes the objective of a supranational elite to build up an entirely economic society. As a behavioural norm this principle penetrates mental situations through the adoption of a neutral and purified form of psychological normality.

This reference to the partial overlap between economic rationality and psychological normality shows that the psychological field falls under the impact of economic imperialism that penetrates all dimensions of human life. Examples of this can be found in the theories and studies of the Chicago School concerning modern marital and flirting practices, as well as in the works of the praxeologist Von Misses and R. Burling (1962).

For all the reasons mentioned above, we cannot express but only naïve optimism in relation to the closure of big asylums institutions and the possibility of integration of mental sufferers in the labour market. The propensity to replace asylums with more flexible structures appeared at the glorious age of the antiPsychiatry wave which demanded for a different - more existential- shift in the perspective under which mental illness had been perceived. During the 1960s and 70s, F. Basaglia in Trieste, R. Laing in London and D. Cooper in Argentina, considered that mental illness is a direct symptom of the repression and alienation imposed or inflicted to human beings by the commercialised society. The establishment of asylums, obviously, belonged to an entirely different perspective on mental health than the current one. Perhaps those schools of 
thought sound rather naïve today, but in those decades of protest the prospect of a less oppressive society seemed like a realistic utopia!

Within the context of today's neo-liberal globalisation we are paradoxically witnessing a certain appropriation of some of the elements of the reasoning of anti-Psychiatry, only this time such elements are completely deviated from their ultimate aims and purposes. The paradox lies in the fact that, by means of elements of the anti-psychiatry reasoning, the authority seeks to transfer responsibility for mental health care from the public sphere to 'civil society' and from there to private sphere.

For all the reasons stated above, we believe that the emphasis placed on mental health and the attempts to remove the stigma from mental sufferers, as well as the replacement of vast and inflexible psychiatric institutions with smaller units, have very few chances of success in their mission to transform and improve the way we view such sufferers. In a world of ruthless antagonism suffering from some form of mental problems is condemned, either in terms of joining subsidised employment and its accompanying poor wages, or, at best, of finding a temporary and precarious employment. Finally, it comes down to the fact that only a society with a less aggressive economic structure could hold the promise of decent standards of living for such citizens.

\section{REFERENCES}

Basaglia, F (2000): "Conferenze braziliane", Rafaelo Cortina Editore (Greek translation: Kastaniotis Publishers, 2006, p.18)

Boyer, R. (1995): “La Flexibilite du Travail en Europe”, PUF, Paris.

Burling, R. (1968): "Maximization theory and the study of economic anthropology" American Anthropologist 64:802-821.

Castoriadis, C. (1991): "Les Carrefours du Labyrinthe", (Greek translation), Ypsilon Publishers, Athens.

Commission Européenne (2005): "Livre Vert: Améliorer la santé mentale de la population : Vers une stratégie sur la santé mentale pour l'Union européenne", Bruxelles, 14.10.2005, COM(2005)484

Equal (2005): "Community's initiative Equal, Action: Developmental partnership SYNERGY",

http://www.equal-greece.gr/groupsubdetailnovelty.asp?Ergonum=25

Foucault, M. (1979) “Histoire de la folie”, Paris, Hatier. 
Gkionakis, N. (2009): post in http://psi-action.blogspot.com/2009/04/blogpost_23.html.

Godelier, M. (1974): "Rationalité et irrationalité en économie", Paris, Editions Maspero.

Lange, O. and Posner, A. (1962): "Economie Politique", Presses universitaires de France.

Lebaube, A. (1990): “L' emploi en miettes”, Hachette, Paris.

Lipietz, A. (1998): "La societé en semblier", La Découverte, Paris.

Megalooikonomou, T. (2006): post in: http://psi-action.blogspot.com/.

Official Gazzete of the Hellenic Republic (1999): Law No. 2716/99 "Development and modernisation of mental health care services", No. 96, volume 1

Photopoulos, T. (2008): "Inclusive Democracy - Ten years later", Free Press Publishing, Athens.

Psychargos (2009): "Official Website of Psychargos Programme", http://www.mohaw.gr/health/programma-psychargos/.

Union of Psychiatric Hospital of Athens (2003): "Declaration of the Scientific Symposium on Primary mental health care and psychiatric reform. http://www.politikokafeneio.com/igia/gimnia114.htm".

Warner, R, (2004): “The environment of schizophrenia”, Kastaniotis, Athens.

Weisskopf, W. (1978): "Alienation, ideologie et depression”, PUF, Paris. 